\title{
A diverse group of halophilic bacteria exist in Lunsu, a natural salt water body of Himachal Pradesh, India
}

\author{
Sonika Gupta, Parul Sharma, Kamal Dev, Malay Srivastava and Anuradha Sourirajan*
}

\begin{abstract}
Five halophilic bacterial isolates namely SS1, SS2, SS3, SS5 and SS8 were isolated from soil sediments of Lunsu, a salty water body. All the bacterial isolates showed growth in LB medium containing up to $8.7 \% \mathrm{NaCl}, \mathrm{pH} 7-8$ and at temperature range of $30-37^{\circ} \mathrm{C}$. The bacterial isolates SS1 and SS3 require at least $3.8 \% \mathrm{NaCl}$ for their growth, indicating their strict halophilic nature. Interestingly, bacterial isolates SS2, SS5 and SS8 but not SS1 and SS3 exhibited growth in medium supplemented with $\mathrm{KCl}$. Accordingly, $\mathrm{Na}^{+}$and $\mathrm{K}^{+}$ions were detected at 1.39 and $0.0035 \%$, respectively in Lunsu water. All the bacterial isolates were analyzed by random amplification of polymorphic DNA (RAPD) using four different random primers and produced PCR fragments ranging from 0.1 to $5 \mathrm{~kb}$ in size. Phylogenetic tree based on RAPD finger prints showed that SS1 and SS3 formed one group, while SS2 and SS5 formed the second group, whereas SS8 was out group. Sequence analysis of 16 S rDNA identified SS1 and SS3 as Halobacillus trueperi, SS2 as Shewanella algae, SS5 as Halomonas venusta, and SS8 as Marinomonas sp. were deposited in GenBank with accession numbers of KM260166, KF751761, KF751760, KF751762 and KF751763, respectively. This is the first report on the presence of diverse halophilic bacteria in the foot hills of Himalayas.
\end{abstract}

Keywords: Halophiles, Lunsu, Phylogenetic, RAPD, 165 rDNA, Blast

\section{Background}

The presence of vast areas of saline water around the earth's surface has provided favourable conditions for the evolution and emergence of salt loving organisms called halophiles. Halophilic microorganisms are primarily found in hypersaline environments and have been reported throughout the world (Oren 2002; Surve et al. 2012). Halophilic microbial communities have been well studied from hyper saline regions such as Great salt lake (USA), Dead Sea (Israel), Wadi Natrun lake (Egypt), lake Magadi (Kenya), soda lake (Antarctica) and Big Soda Lake and Mono Lake (California) (Litchfield and Gillevet 2002; DasSarma and DasSarma 2012). Hyper saline regions differ from each other in terms of salt concentration, chemical composition and geographical location, which determine the nature of inhabitant microorganisms.

*Correspondence: asourirajan@gmail.com

Faculty of Biotechnology, Shoolini University, Solan 173212,

Himachal Pradesh, India
Halophiles are found in all the three domains of life such as Archaea (e.g., Halobacterium sp.), bacteria (e.g., Halobacillus sp.) and eukaryotes (e.g., green algae, Dunaliella salina, brine shrimp, Artemia franciscana and halophytic plant, Atriplex halimus) (DasSarma and DasSarma 2012). The cultured diversity of halophilic Archaea includes 47 genera and 165 species of the family Halobacteriaceae (Oren 2014). Hyper saline environments are predominantly inhabited by both extremely halophilic and halotolerant microorganisms such as Halobacterium sp., Haloferax sp., Haloarcula sp., Halobacillus sp., Salinibacter ruber, Virgibacillus salarius, Bacillus spp. and Micrococcus luteus (Paterekt and Smith 1985; Arahal et al. 1996; Anton et al. 2002; Solanki and Kothari 2012; Solomon and Viswalingam 2013). Halophilic microorganisms require at least $0.2 \mathrm{M}$ salt for their growth and cannot grow in the absence of salt. On the other hand, halotolerant bacteria grow in the absence of salt as well as in the presence of relatively high salt concentrations (e.g., Staphylococcus aureus and Vibrio sp.) (Ara et al. 2013).

\section{Springer}

(c) 2015 Gupta et al. This article is distributed under the terms of the Creative Commons Attribution 4.0 International License (http://creativecommons.org/licenses/by/4.0/), which permits unrestricted use, distribution, and reproduction in any medium, provided you give appropriate credit to the original author(s) and the source, provide a link to the Creative Commons license, and indicate if changes were made. 
Halophiles possess the ability to balance the osmotic pressure of the environment. To do so, they either accumulate compatible solutes or uptake $\mathrm{K}^{+}$ions in exchange of $\mathrm{Na}^{+}$ions (Galinski 1993; Waditee et al. 2002; Roberts 2005; Ghasemi et al. 2011) or use both strategies (hybrid strategy) together (Saum et al. 2012; Hänelt and Müller 2013). Modification of membrane composition (Sakamoto and Murata 2002) and induction of general stress tolerance proteins are other means used by halophiles to cope up with salt stress (Hillmann et al. 2006; Kapardar et al. 2010).

There is a tremendous demand for halophilic bacteria due to their biotechnological importance as sources of halophilic enzymes, fermentation of soy and fish sauce, biological treatment of saline wastewater and production of $\beta$-carotene, compatible solutes, bioplastics and bio fuel (Oren 2010; Li and Yu 2012). In addition, halophilic microbes serve as an attractive source of salt-tolerance genes for the generation of salt resistant transgenic plants (Kapley et al. 1999; Gisbert et al. 2000; Klahn et al. 2009).

In India, halophilic micro flora have been reported from natural hyper saline habitats from the coastal regions of Maharashtra, Gujarat, Tamil Nadu, Goa and desert state of Rajasthan (Kokare et al. 2004, Dodia et al. 2006, Vijayanand et al. 2012, Surve et al. 2012, and Nigam et al. 2013). The bacteria reported from these locations (e.g., Alkalibacillus sp. A1, Virgibacillus sp. V1 and Actinopolyspora sp. AH1) are halo-alkaliphilic in nature, and exhibit optimal growth in the presence of $5-20 \% \mathrm{NaCl}$ and $\mathrm{pH} 8-10$. In Himachal Pradesh, the hill state of India, there are two salt water bodies, one located in Gumma (Mandi district) and other in Lunsu (Kangra district). However, these saltern water bodies have not yet been explored for the presence of halophilic microbes. Therefore, we underlook this study to isolate and characterise the halophilic bacteria from Lunsu. Our results reveal the existence of strict halophilic as well as halotolerant bacteria in the sediment of Lunsu salt water stream.

\section{Methods}

\section{Growth media}

The media used in the present study were of microbiological grade, and procured from Himedia Labs, Mumbai. The halophilies were isolated and cultured in Luria broth (LB) or minimal M9 medium supplemented with $\mathrm{NaCl}$ (Sambrook et al. 2009).

\section{Sampling site and sample collection}

Soil samples were collected in sterile $50 \mathrm{ml}$ centrifuge tubes from the Lunsu water body situated in Kangra, Himachal Pradesh, India. The Lunsu water body is $10 \mathrm{~km}$ from Kangra railway station and located at the longitude of 76.1667362 and latitude of 32.0067136 . The literal meaning of "luun" is salt in local language, and hence named Lunsu. Soil sample ( $\sim 5 \mathrm{~g})$ was collected from water body site and mixed with $5 \mathrm{ml}$ of $2 \times$ LB medium containing $3 \% \mathrm{NaCl}$ and incubated at $30^{\circ} \mathrm{C}$ for 3 days, with intermittent mixing for the enrichment of halophilic bacteria. For estimation of salts in Lunsu water, water sample was collected in sterile $50 \mathrm{ml}$ centrifuge tubes.

\section{Chemical analysis of water sample}

The $\mathrm{pH}$ of water sample was recorded using digital $\mathrm{pH}$ meter and $\mathrm{pH}$ indicator paper. The salinity of water was determined by quantitation of $\mathrm{Cl}^{-}$ions by $\mathrm{AgNO}_{3}$ titration (Greenberg et al. 1992) and conductivity meter. Flame photometer was used to determine the amount of $\mathrm{Na}^{+}$and $\mathrm{K}^{+}$ions in water sample. Tap water was used as a negative control. The concentration of $\mathrm{Na}^{+}$and $\mathrm{K}^{+}$ions were calculated using $\mathrm{NaCl}$ and $\mathrm{KCl}$ standard, respectively.

\section{Isolation of halophilic bacteria from soil sample}

To isolate the micro flora from soil sample of Lunsu water body, serial dilutions $\left(10^{-1}\right.$ to $\left.10^{-5}\right)$ of enriched micro flora were spread on LB agar medium or LB agar medium supplemented with $1 \mathrm{M} \mathrm{NaCl}$, and incubated at $30^{\circ} \mathrm{C}$ for $24 \mathrm{~h}$. The individual colonies obtained were counted and expressed as colony forming units (CFU/g of soil) to estimate microbial load. The bacterial isolates were selected based on the size, shape, colour and texture, and purified by three successive streaking on LB agar medium containing $5.8 \% \mathrm{NaCl}$. Purified bacterial isolates were verified by Gram's staining and microscopic examination. Escherichia coli $\mathrm{DH} 5 \alpha$, the laboratory strain, was used as a non-halophilic control for growth on medium supplemented with $\mathrm{NaCl}$. The purified bacterial isolates were cultured and maintained on LB agar containing 5.8\% $\mathrm{NaCl}$.

\section{Biochemical characterisation of halophilic bacterial isolates}

Bacterial isolates were studied for Gram's reaction, cell morphology and pigmentation. Enzymatic assays (oxidase, catalase, nitrate reductase and urease), and assays for fermentation of lactose and mannitol were done as described by Smibert and Krieg (1994).

\section{Optimization of growth conditions}

Different physical (pH and temperature) and nutritional (carbon and nitrogen sources) parameters were optimized for the growth of halophilic bacterial isolates. Growth parameters were studied qualitatively by streaking the bacterial isolates on LB agar medium and quantitatively by growing the bacterial isolates in LB or minimal 
medium (M9) at $30^{\circ} \mathrm{C}$ with shaking at $200 \mathrm{rpm}$ for $24 \mathrm{~h}$ and measuring the cell density at $600 \mathrm{~nm}$. To study the effect of $\mathrm{NaCl}$ or $\mathrm{KCl}$ on the growth, bacterial isolates were streaked on LB or M9 agar medium supplemented with different concentration of $\mathrm{NaCl}(0-29 \%)$ or $\mathrm{KCl}$ $(0-18.3 \%)$. The effect of $\mathrm{pH}$ on the growth of halophilic bacterial isolates was studied by streaking halophilic bacterial isolates on above described growth media containing $\mathrm{NaCl}$ and adjusted to acidic $\mathrm{pH}$ of 5 and 6 by using $1 \mathrm{~N} \mathrm{HCl}$ and alkaline $\mathrm{pH}$ of $8,9,10,11$ and 12 using $5 \mathrm{~N}$ $\mathrm{NaOH} \cdot$ The petriplates were incubated at $30^{\circ} \mathrm{C}$ for $24 \mathrm{~h}$ and observed for growth. The effect of temperature was studied by culturing the bacterial isolates in LB or M9 media at different temperature of incubation $\left(15-50^{\circ} \mathrm{C}\right)$ for $24 \mathrm{~h}$. The effect of carbon and nitrogen sources was studied by comparing the growth of isolates in M9 medium supplemented with different carbon sources (2\%) such as glucose, starch, sucrose, fructose, trehalose, glycerol, lactose, raffinose, galactose, and sorbitol, and various nitrogen sources $(0.25 \%)$, such as yeast extract, peptone, beef extract, casein hydrolysate, and urea respectively.

\section{Molecular characterization of halophilic bacterial isolates by RAPD and $16 \mathrm{~S}$ rDNA analysis}

The halophilic bacterial isolates were cultured in their optimal growth conditions to an $\mathrm{A}_{600}$ of $\sim 1.0$ and the cells were harvested by centrifugation at $12,000 \mathrm{~g}$ for $5 \mathrm{~min}$. Genomic DNA from each of the bacterial cell pellet was isolated as described by Sambrook et al. (2009).

To study the genetic relationship between the halophilic bacterial isolates, $100 \mathrm{ng}$ of genomic DNA was subjected to PCR by using four different random primers named as $1 \mathrm{~K}, 2 \mathrm{~K}, 15 \mathrm{~K}$ and $25 \mathrm{~K}$ (Additional file 1 : Table S1). The PCR reaction conditions were set as initial denaturation at $94^{\circ} \mathrm{C}$ for 2 min followed by 35 cycles of denaturation $\left(94^{\circ} \mathrm{C}, 30 \mathrm{~s}\right)$, annealing $\left(40^{\circ} \mathrm{C}, 30 \mathrm{~s}\right)$, and extension $\left(72^{\circ} \mathrm{C}, 2 \mathrm{~min}\right)$, with a final extension of $10 \mathrm{~min}$ at $72^{\circ} \mathrm{C}$. The amplified products were separated by electrophoresis on $1.2 \%$ agarose gel, stained with ethidium bromide $(0.5 \mu \mathrm{g} / \mathrm{ml})$ and visualised in UV gel documentation system (Alpha Innotech, USA). Towards molecular identification of halophilic bacterial isolates, $100 \mathrm{ng}$ of total genomic DNA was subjected to PCR amplification of $16 \mathrm{~S}$ rDNA gene using $27 \mathrm{~F}$ and $1492 \mathrm{R}$ primers (Additional file 1: Table S1; Lane 1991). The PCR thermal cycling conditions were set as initial denaturation at $94^{\circ} \mathrm{C}$ for 2 min followed by 35 cycles of denaturation $\left(94^{\circ} \mathrm{C}, 30 \mathrm{~s}\right)$, annealing $\left(45^{\circ} \mathrm{C}, 30 \mathrm{~s}\right)$, and extension $\left(72^{\circ} \mathrm{C}, 2 \mathrm{~min}\right)$, with a final extension of $10 \mathrm{~min}$ at $72^{\circ} \mathrm{C}$. The PCR products were resolved on $1 \%$ agarose gel and visualised as described above. The gel purified PCR products of $16 \mathrm{~S}$ rDNA gene were sequenced on both strands using the primers $27 \mathrm{~F}$ and $1492 \mathrm{R}$ at Eurofins, Bangalore, India (https://www.eurofins.com). The nucleotide sequence thus obtained were manually analysed, overlapping sequences were removed and the complete $16 \mathrm{~S}$ rDNA sequence for each bacterial strain was generated. Nucleotide sequences were analysed by BLAST (blastn) search and compared against bacterial 16S rDNA sequences available in the Gene bank data base (Alschul et al. 1990). The sequences were aligned by using Clustal W 1.74 (Thompson et al. 1994), followed by construction of neighbour joining phylogenetic tree using MEGA4 (http://www.megasoftware.net) (Tamura et al. 2007). The nucleotide sequences were submitted in the GenBank data base (https://www.ncbi.nlm.nih.gov/genbank/).

\section{Results}

\section{$\mathrm{NaCl}$ is the predominant salt in Lunsu water}

Lunsu is a saltern water body that originates from the Rocky Mountains in the foot hills of Himalaya (Additional file 2: Figure S1). At the time of sample collection, the $\mathrm{pH}$ of water sample was slightly acidic $(\mathrm{pH} 6)$, and the temperature was $21^{\circ} \mathrm{C}$ at noon time. The water sample tested positive for the presence of salts by conductivity tests. Volumetric analysis revealed that the concentration of sodium chloride was $1.39 \%$. By using flame photometric assay, it was found that Lunsu water contains 500 times more sodium ions $(1.39 \%)$ as compared to potassium ions $(0.0035 \%)$.

\section{Halophilic and halotolerant bacteria are present in the soil sediments of Lunsu water body}

To explore the presence of halophiles in the Lunsu water body, soil sediments were spread on bacterial growth medium in the absence and presence of $\mathrm{NaCl}$. Microbial growth was observed in both the media, with the microbial load of $4 \times 10^{5} \mathrm{CFU} / \mathrm{g}$ of soil on LB, and $3 \times 10^{4} \mathrm{CFU} / \mathrm{g}$ of soil on LB medium supplemented with $1 \mathrm{M} \mathrm{NaCl}$. Colonies of different colours (yellow, orange, creamish and white) were observed. Very interestingly, yellow/orange pigmented colonies showed growth only on medium supplemented with $\mathrm{NaCl}$ (data not shown). This indicates that yellow/orange pigmented colonies are strict halophiles, which require $\mathrm{NaCl}$ for growth; whereas white/creamish coloured colonies do not require $\mathrm{NaCl}$ for growth. This data is in agreement with the fact that the soil sediment of Lunsu water body naturally appears orange in colour (Additional file 2: Figure S1).

\section{Morphological and biochemical characteristic features of halophilic bacterial isolates}

A total of five distinct bacterial isolates (SS1, SS2, SS3, SS5 and SS8) were isolated from soil sediments of Lunsu (Figure 1). The colour of the isolates varied from 


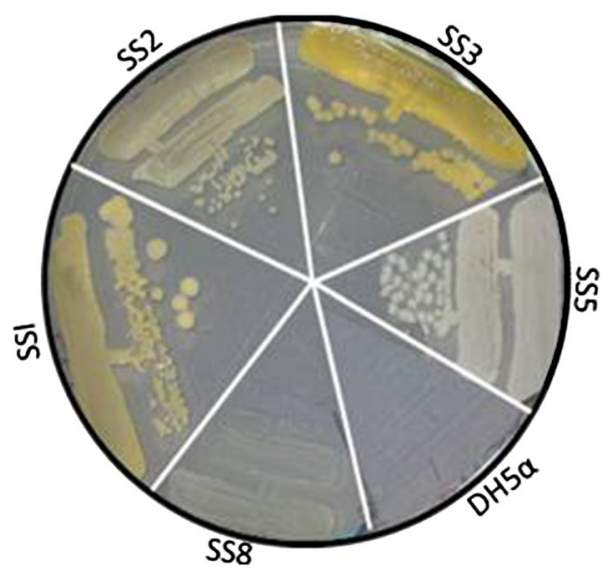

Figure 1 Growth of halophilic bacterial isolates. Purified bacterial strains as indicated were streaked on LB agar medium supplemented with $1 \mathrm{M} \mathrm{NaCl}$ and incubated for $48 \mathrm{~h}$ at $37^{\circ} \mathrm{C}$. E. coli strain $\mathrm{DH} 5 \alpha$ was used as non-halophilic control. creamish, whitish, pale yellow to orange (Table 1). The bacterial isolates SS1, SS2, SS3 and SS5 were motile, rod shaped and catalase positive, where as SS8 was cocci shaped, catalase and oxidase negative (Table 1). Bacterial isolates SS1 and SS3 were positive for mannitol fermentation and negative for oxidase and nitrate tests. Urease activity was observed in all the bacterial isolates, except SS1. All the bacterial isolates were negative for lactose fermentation.

\section{SS1 and SS3 are strict halophiles while SS2, SS5 and SS8 are halotolerant bacteria}

We isolated halophilic bacteria on growth medium with or without $\mathrm{NaCl}$ supplementation at $\mathrm{pH} 7$ and temperature of $30^{\circ} \mathrm{C}$. Moreover, we detected both $\mathrm{Na}^{+}$and $\mathrm{K}^{+}$ ions in the water sample. Therefore, we studied the effect of $\mathrm{NaCl}, \mathrm{KCl}$, temperature and $\mathrm{pH}$ on the growth of bacterial isolates. Out of the five bacterial isolates, SS1 and

Table 1 Biochemical and growth characteristics of the halophilic bacterial isolates of Lunsu

\begin{tabular}{|c|c|c|c|c|c|c|c|}
\hline \multicolumn{3}{|c|}{ Cellular/biochemical and growth parameter } & \multicolumn{5}{|c|}{ Halophilic bacterial isolate } \\
\hline & & & \multirow{2}{*}{$\begin{array}{l}\text { SS1 } \\
\text { Rods }\end{array}$} & \multirow{2}{*}{$\begin{array}{l}\text { SS2 } \\
\text { Rods }\end{array}$} & \multirow{2}{*}{$\begin{array}{l}\text { SS3 } \\
\text { Rods }\end{array}$} & \multirow{2}{*}{$\begin{array}{l}\text { SS5 } \\
\text { Rods }\end{array}$} & \multirow{2}{*}{$\frac{\text { SS8 }}{\text { Cocci }}$} \\
\hline A & Cell morpl & & & & & & \\
\hline B & Motility & & + & + & + & + & + \\
\hline C & Pigmentat & & Pale yellow & Whitish & Yellowish & Whitish & Creamish \\
\hline D & Gram's rea & & + & - & + & - & - \\
\hline E & Catalase & & + & + & + & + & - \\
\hline $\mathrm{F}$ & Oxidase & & - & + & - & + & + \\
\hline G & Nitrate & & - & + & - & - & + \\
\hline H & Urease & & - & + & + & + & + \\
\hline । & Mannitol $f$ & tation & + & - & + & - & - \\
\hline J & $\mathrm{NaCl}(\%) \mathrm{O}$ & m concentration (range) & $11.6(3.8-26.1)$ & $4.3(0-8.7)$ & $11.6(3.8-26.1)$ & $8.7(14.5)$ & $2.9(0-8.7)$ \\
\hline K & $\mathrm{KCl}(\%) \mathrm{op}$ & concentration (range) & - & $3.7(0-7.4)$ & - & $7.4(0-14.8)$ & $3.7(0-7.4)$ \\
\hline L & $\mathrm{pH}$ for gro & ptimum pH (range) & $9(7-12)$ & $7(6-12)$ & $9(7-12)$ & $8(6-12)$ & $7(6-8)$ \\
\hline M & $\begin{array}{l}\text { Temperatc } \\
\text { (range) }\end{array}$ & optimum temperature & $37(25-40)$ & $37(25-40)$ & $37(25-40)$ & $37(15-40)$ & $30(15-37)$ \\
\hline N & Glucose & Yeast extract & - & - & - & - & - \\
\hline $\mathrm{O}$ & Glucose & Beef extract & + & + & - & + & + \\
\hline$P$ & Glucose & Peptone & + & + & - & + & + \\
\hline Q & Glucose & Casein hydrolysate & + & + & + & + & + \\
\hline R & Raffinose & Casein hydrolysate & - & - & - & + & - \\
\hline$S$ & Lactose & Casein hydrolysate & - & - & - & + & - \\
\hline $\mathrm{T}$ & Trehalose & Casein hydrolysate & - & - & - & + & - \\
\hline U & Starch & Casein hydrolysate & - & - & - & + & - \\
\hline V & Galactose & Casein hydrolysate & - & - & - & + & - \\
\hline W & Fructose & Casein hydrolysate & - & - & - & + & - \\
\hline$x$ & Sucrose & Casein hydrolysate & - & - & - & + & - \\
\hline Y & Sorbitol & Casein hydrolysate & - & - & - & + & - \\
\hline Z & Glycerol & Casein hydrolysate & - & - & - & + & - \\
\hline
\end{tabular}

Plus (+) sign indicates the test as positive, where as negative (-) sign indicates negative results for biochemical test. Plus (+) sign indicates the growth of bacterial isolate and negative (-) sign indicates no detectable growth when streaked or spotted on LB/M9 agar medium. 
SS3 did not show any growth on LB containing less than $3.8 \% \mathrm{NaCl}$ (Table 1) and exhibited growth up to $26.1 \%$ $\mathrm{NaCl}$, thus indicating the strictly halophilic nature of the isolates. However, no detectable growth of SS1 and SS3 was observed in the presence of $\geq 0.74 \% \mathrm{KCl}$ (Table 1).

The bacterial isolates SS2 and SS8 exhibited growth even in absence of $\mathrm{NaCl}$ or $\mathrm{KCl}$ and tolerated up to $8.7 \%$ $\mathrm{NaCl}$ or $7.4 \% \mathrm{KCl}$ (Table 1). The bacterial isolate SS5 showed growth in absence or presence of $\mathrm{NaCl}$ or $\mathrm{KCl}$, and growth was observed up to $14.5 \% \mathrm{NaCl}$ or $14.8 \% \mathrm{KCl}$. Based on these observations, we conclude that bacterial isolates SS2, SS5 and SS8 are halotolerant bacteria.

The optimum growth of isolates SS1 and SS3 was observed in the presence of $11.6 \% \mathrm{NaCl}$, whereas it was 8.7, 4.3 and $2.9 \% \mathrm{NaCl}$ for SS5, SS2 and SS8 respectively. While SS1 and SS3 did not show any growth in the presence of $\mathrm{KCl}$, SS5 showed optimum growth in the presence of $7.4 \% \mathrm{KCl}$ and SS2 and SS8 in the presence of 3.7\% $\mathrm{KCl}$ (Table 1).

\section{SS1, SS3 and SS5 are haloalkaliphilic while SS2 and SS8 are} haloneutrophilic in nature

The halophilic isolates SS1 and SS3 showed growth in LB medium supplemented with $11.6 \% \mathrm{NaCl}$ and $\mathrm{pH}$ range of 7-12. The optimum pH for the growth of SS1 and SS3 was 9 and they did not show any detectable growth at or below pH 6 (Table 1), which indicates the alkaliphilic nature of SS1 and SS3 isolates.

The bacterial isolates SS2 and SS5 exhibited growth in the range of $\mathrm{pH} 6-12$, while SS8 did not show any growth at $\mathrm{pH}$ greater than 8 . The optimum $\mathrm{pH}$ for growth of strain SS5 was $\mathrm{pH}$ 8.0, whereas for SS2 and SS8 was $\mathrm{pH}$ 7.0 (Table 1). These results indicate that SS1, SS3 and SS5 are alkaliphilic, while SS2 and SS8 are neutrophilic in nature.

Two halophiles (SS1 and SS3) and two halotolerants (SS2 and SS5) showed growth between 25 and $40^{\circ} \mathrm{C}$ in LB medium supplemented with 11.6 and $5.8 \% \mathrm{NaCl}$ respectively, with an optimum growth at $37^{\circ} \mathrm{C}$ (Table 1). The bacterial isolate SS8 exhibited optimal growth at $30^{\circ} \mathrm{C}$, poor growth at $37^{\circ} \mathrm{C}$ and no detectable growth at $40^{\circ} \mathrm{C}$. Also, detectable growth of halophilic isolates SS5 and SS8 was observed at $15^{\circ} \mathrm{C}$ after incubation of $72 \mathrm{~h}$. However, none of the bacterial strains could grow below $15^{\circ} \mathrm{C}$ and above $45^{\circ} \mathrm{C}$ (Table 1$)$.

\section{The halophilic and halotolerant bacterial isolates exhibit complex growth requirement}

To characterise the growth in minimal and defined medium, we studied the effect of different carbon and nitrogen sources on the growth of halophilic bacterial isolates. It was observed that Minimal medium (M9) containing glucose as a carbon source and ammonium chloride as a nitrogen source did not support growth of any of the halophilic isolates (Table 1). More importantly, growth was also not observed when ammonium chloride was replaced with urea or yeast extract as a nitrogen source. The addition of casein hydrolysate as a nitrogen source supported the growth of all the halophilic isolates (Table 1). Since glucose as carbon source and casein hydrolysate as a nitrogen source supported the growth of all the bacterial isolates, we studied the effect of different carbon sources in M9 medium supplemented with casein hydrolysate as nitrogen source. Very surprisingly, none of the bacterial isolates, except SS5, showed growth when glucose, starch, sucrose, fructose, trehalose, glycerol, lactose, raffinose, galactose or sorbitol was supplemented as carbon source (Table 1). All halophilic isolates showed growth in presence of peptone and beef extract except isolate SS3. (Table 1). Together, these results indicate a complex requirement of carbon and nitrogen sources by the halophilic bacterial isolates of Lunsu. The effect of temperature, $\mathrm{pH}$ and $\mathrm{NaCl}$ concentrations were also studied in M9 medium supplemented with casein hydrolysate and glucose (data not shown). There was no significant difference in the optimum $\mathrm{pH}$, temperature or salt requirement as compared to those in LB medium (Table 1).

\section{Halophilic bacterial isolates of Lunsu are phylogenetically different}

Each of the five halophilic bacterial isolate (SS1, SS2, SS3, SS5 and SS8) showed distinct morphological and physiological characteristic features. In order to confirm their distinctness at the molecular level, RAPD analysis was performed using a set of four random primers (Additional file 1: Table S1). The total genomic DNA of halophilic bacterial strains was isolated (Additional file 3: Figure S2a) and subjected to RAPD amplification using random decamer primers. RAPD analysis revealed differences in the number and banding pattern of each of the five isolates (Additional file 3: Figure S2b-e). In general, the size of DNA amplification products varied from 0.1 to $5 \mathrm{~kb}$. The primer $1 \mathrm{~K}$ generated PCR products ranging 0.25-3.2 kb (Additional file 3: Figure S2b), primer $2 \mathrm{~K}$ between 0.75 and $3 \mathrm{~kb}$ (Additional file 3: Figure S2c), primer $15 \mathrm{~K}$ between 0.1 and $4.8 \mathrm{~kb}$ (Additional file 3: Figure 2Sd) and primer $25 \mathrm{~K}$ between 0.2 and $5 \mathrm{~kb}$ (Additional file 3: Figure 2Se). The largest number of polymorphic bands was observed with primer $15 \mathrm{~K}$, followed by $1 \mathrm{~K}, 25 \mathrm{~K}$ and $2 \mathrm{~K}$. Thus, RAPD analysis revealed that all the five halophilic isolates are genetically distinct, with close relatedness in SS1and SS3, SS2 and SS5, while SS8 being a divergent member. 
Molecular identification of the halophilic bacterial isolates In order to identify the halophilic bacterial isolates, $16 \mathrm{~S}$ rDNA gene was amplified using gene specific primers. A PCR product of $\approx 1.5 \mathrm{~kb}$ was detected in all the five isolates. The $16 \mathrm{~S}$ rDNA amplicons of each bacterial isolate was sequenced on both strands using $27 \mathrm{~F}$ and 1492R primers. The complete nucleotide sequence of 1,461 , $1,412,1,437,1,408$ and 1,416 bp sequences were obtained from SS1, SS2, SS3, SS5 and SS8 isolates respectively, and subjected to BLAST analysis. 16S rDNA sequence analysis showed that the isolated strains belong to the genera Halobacillus, Shewanella, Halomonas and Marinomonas. The halophilic isolates SS1 and SS3 showed 98 and 99\% similarity, respectively with Halobacillus trueperi DSM10404 (accession no. NR_025459.1). The isolates SS5 and SS8 showed 98\% similarity with Halomonas venusta DSM4743 (accession no. NR_042069.1) and Marinomonas sp. BSi20328 (accession no. NR_043882.1), respectively. The bacterial isolate SS2 showed 99\% sequence similarity with Shewanella algae OK-1 (accession no. NR_028673.1). The 16S rDNA nucleotide sequences of all the five halophilic bacterial strains have been submitted to the NCBI GenBank database under the accession nos. KM260166 (Halobacillus trueperi strain SS1), KF751760 (Shewanella algae strain SS2), KF751761 (Halobacillus trueperi strain SS3), KF751762 (Halomonas venusta strain SS5) and KF751763 (Marinomonas strain SS8).

To validate the molecular identity of the five halophilic bacterial strains of Lunsu, phylogenetic analysis of $16 \mathrm{~S}$ rDNA was carried out for all the five halophilic bacterial strains along with the isolates showing more than 90\% similarity. The halophilic bacterial isolates formed five independent clusters and showed genetic relatedness to the members of their respective genera (Figure 2). Halobacillus trueperi SS3 evolutionarily evolved with Halobacillus trueperi DSM10404 and Halobacillus faecis IGA7-4. On the other hand, Halobacillus trueperi SS1 formed a separate clad from the other members of the Halobacillus spp. It is also important to note that Halobacillus trueperi strain SS1 and Halobacillus trueperi strain SS3 fall into separate phylogenetic clads, despite living in a common habitat. Shewanella algae SS2 clustered with Shewanella haliotis DW01, despite of its 99\% sequence similarity with Shewanella algae OK-1 (accession no. NR_028673.1). Halomonas venusta strain SS5 formed a cluster with Halomonas aquamarina DSM30161 and $H$. axialensis despite its similarity (99\%) with Halomonas venusta DSM4743. Marinomonas strain SS8 co-evolved with Marinomonas sp. BSi20328 (Figure 2).

\section{Discussion}

Recent decades have seen a rise in studies on microorganisms isolated from extreme environments, including hyper saline ecosystems. Both molecular and microbiological studies have revealed the existence of moderate to extremely halophilic micro and some macro-organisms in a wide range of these saline environments (Ventosa et al. 1998; Roohi et al. 2012; Hedi et al. 2014). In the present study, five bacterial strains have been isolated from the soil sediments of Lunsu water body of Himachal Pradesh, India.

The present study showed that Lunsu water sample contains $1.38 \% \mathrm{Na}^{+}$ions $(1.38 \% \mathrm{NaCl})$ and $0.0035 \% \mathrm{~K}^{+}$ ions $(0.0035 \% \mathrm{KCl})$, which is 24 times more than the amount of $\mathrm{Na}^{+}$ions in tap water. The high concentration of $\mathrm{NaCl}$ in the water was consistent with the fact that the water of Lunsu has an unbearable salty taste (observations of the local people). The salt content estimates indicate that the Lunsu water body represents a moderately hyper saline environment. Several hyper saline environments have been studied worldwide, of which Dead Sea has the maximum salt content (DasSarma and Arora 2001; Grant 2004). It has been reported that the concentration of $\mathrm{NaCl}$ and $\mathrm{KCl}$ in Dead Sea ranges from 7.1 to $9.1 \%$ and 1.5 to $1.7 \%$, respectively (Wisniak 2002). Amongst the hypersaline habitats in India, the Lonar Lake in Maharashtra has been reported to contain $0.35 \%$ $\mathrm{Na}^{+}$and $0.0017 \% \mathrm{~K}^{+}$ions (Pedge and Ahirrao 2013).

The halophilic bacterial isolates SS1 and SS3 showed growth at temperature of $25-40^{\circ} \mathrm{C}, \mathrm{pH} 7.0-12.0$ and 3.8-26.1\% NaCl. Bacterial isolate SS5 showed detectable growth at the temperature of $15-40^{\circ} \mathrm{C}, \mathrm{pH}$ 6.0-12.0 and in the presence of $0-14.5 \% \mathrm{NaCl}$ whereas SS8 showed growth at temperature of $15-37^{\circ} \mathrm{C}, \mathrm{pH} 6.0-8.0$ and in the presence of $0-8.7 \% \mathrm{NaCl}$. The growth of bacterial isolate SS2 was observed in the presence of $0-8.7 \% \mathrm{NaCl}$, $\mathrm{pH} 7.0-12.0$ and temperature of $25-40^{\circ} \mathrm{C}$. Kanekar et al. (2008) isolated Gram's positive bacterial strains from Lonar Lake, which showed optimum growth at $23^{\circ} \mathrm{C}, \mathrm{pH}$ 9.8 and $4.5 \% \mathrm{NaCl}$. Vidyasagar et al. (2007) isolated gram negative, rod shaped halophilic strains from solar evaporation pond with optimum growth at $23 \%(\mathrm{w} / \mathrm{v}) \mathrm{NaCl}$. Patel et al. (2010) have reported halophilic gram-negative strains from the Arabian coasts, Gujarat, India. However, there are no reports on halophiles from Northern India, including Himachal Pradesh. Thus, our study forms the first report on the characterization of halophiles from Northern India.

The molecular identification of the halophiles from Lunsu revealed that the SS1 and SS3, are $\geq 98 \%$ identical Halobacillus trueperi and SS2, SS5 and SS8 are identical to Shewanella algae, Halomonas venusta and Marinomonas sp. respectively. Spring et al. (1996) described the isolation of orange pigmented Halobacillus trueperi from Great Salt Lake in Utah, which exhibited growth at temperature range of $10-44^{\circ} \mathrm{C}$ and $\mathrm{pH}$ 


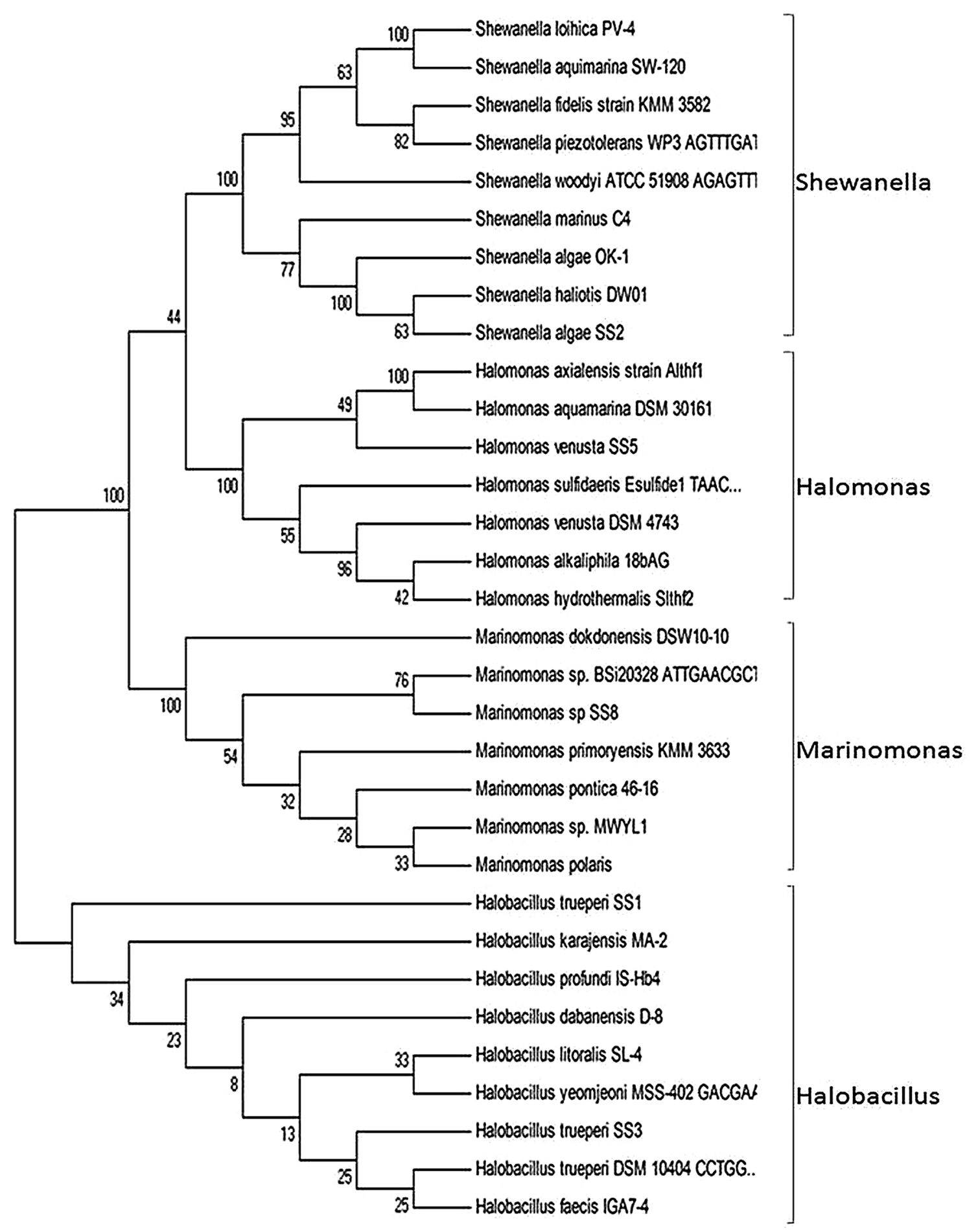

Figure 2 Phylogenetic analysis of halophilic bacterial isolates based on 165 rDNA sequences. Neighbour-joining phylogenetic trees depicting the interrelationships of 16 S rDNA sequence of halophilic isolates SS1, SS3, SS2, SS5 and SS8 with closely related halophilic isolates of their respective genera.

$6.0-9.5$ in the presence of $0.5-30 \%(\mathrm{w} / \mathrm{v}) \mathrm{NaCl}$. Recently, rod shaped, creamish pigmented Halobacillus sp. has been reported from Sehline Sebkha salt lake, Tunisia, which showed growth in presence of $5-25 \%(\mathrm{w} / \mathrm{v}) \mathrm{NaCl}$ at $37^{\circ} \mathrm{C}$ (Hedi et al. 2014). Similarly, halophilic bacterial isolates Halobacillus trueperi SS1 and SS3 of Lunsu 
have yellow-orange pigmentation and exhibit growth in the presence of $4-26.1 \%(\mathrm{w} / \mathrm{v}) \mathrm{NaCl}, \mathrm{pH} 7-12$ and temperature $25-40^{\circ} \mathrm{C}$. In addition, Halobacillus trueperi SS1 and SS3 failed to grow in presence of $\mathrm{KCl}$ and below 3.8\% $\mathrm{NaCl}$. No such reports exist about Halobacillus trueperi from other studies. Together, our study indicates that Halobacillus trueperi SS1 and SS3 exhibit significant differences in their growth characteristics from known species of this genus.

Generally, Halomonas sp. are creamish to whitish in colour (Mata et al. 2002), except that Halomonas venusta ATCC 27125 was found to be yellow in colour and exhibited growth in the presence of $0-20 \%(\mathrm{w} / \mathrm{v}) \mathrm{NaCl}, \mathrm{pH}$ 5-10 and temperature ranging from 4 to $45^{\circ} \mathrm{C}$ (Mata et al. 2002). The halophilic bacterial strain SS5 of Lunsu has 98\% identity with Halomonas venusta DSM 4743. Halomonas venusta SS5 showed similar properties (Table 1) with exception to the whitish colour as reported by Mata et al. 2002.

The halo bacterial strain SS2 of Lunsu exhibited 99\% sequence similarity to Shewanella algae OK-1. Most of the species of these genera have been isolated from marine regions and thus consistent of being halotolerant in nature. For example, Shewanella haliotis DW01T was isolated from the gut micro flora of abalone collected from the South Sea (Kim et al. 2007). Another bacterial strain Shewanella algae ATCC 51192 was isolated from salt marshes that formed pink colour colonies and showed salt tolerance up to $6 \%(\mathrm{w} / \mathrm{v}) \mathrm{NaCl}$ (Nozue et al. 1992). On the other hand Shewanella algae SS2 isolated in the present study is whitish in colour and exhibited growth in the presence of $0-8.7 \%(\mathrm{w} / \mathrm{v}) \mathrm{NaCl}$.

Recently, Halomonas sp. and Shewanella sp. were also reported from the foreshore soil of Daecheon beach and Saemangeum sea of Korea (Irshad et al. 2014). As the name suggests, members of Marinomonas have been isolated from marine and coastal regions (Dong et al. 2014). It is interesting to note that halophiles found in marine areas (Shewanella sp. and Marinomonas sp.) also inhabit the hilly saline water of Lunsu. Marinomonas strain IVIA-Po-185T and M. pontica 46-16 have been isolated from the sea grass Posidonia oceanic. They are helical in shape, have salt tolerance up to $10 \%$ and grow at temperatures between $5-37^{\circ} \mathrm{C}$ and $4-33^{\circ} \mathrm{C}$, respectively (Espinosa et al. 2010). The halotolerant isolate Marinomonas sp. SS8 of Lunsu showed similar features including growth temperature of $15-37^{\circ} \mathrm{C}$ and salt tolerance up to $8.7 \%(\mathrm{w} / \mathrm{v}) \mathrm{NaCl}$.

\section{Conclusion}

To our knowledge, this is the first study on the microbial diversity of halophilic bacterial community inhabiting the saltern water body. Two types of halophilic and halotolerant bacteria have been isolated from soil sediment of Lunsu, which are phylogeneticaly different. Culturing of microbes and their molecular analysis provides an opportunity to have a wide range of cultured microorganisms from the extreme environments. The microbial diversity of extremophiles can prove to be a valuable resource in various industrial and biotechnological processes requiring specialised features. Halophiles offer an added advantage to be a source of gene(s) that can increase salt tolerance in different crops through genetic engineering techniques. Thus, the halophiles isolated from Lunsu water body offer an important potential for application in microbial, enzyme and agricultural biotechnology.

\section{Additional files}

Additional file 1: Table S1. Primers used in the present study.

Additional file 2: Figure S1. Source of halophilic microbial isolates. A picture of Lunsu water body in Lunsu village, Kangra district, Himachal Pradesh, India. The location of sample collection is indicated.

Additional file 3: Figure S2. RAPD- PCR analysis of halophilic microbial isolates. (a) Genomic DNA of halophilic bacterial strains was isolated and electrophoresed on $1 \%$ agarose gel. Lane M indicates the DNA molecular size marker (kb) and genomic DNA in other lanes as indicated. b-e: PCR amplified products using random primers $1 \mathrm{~K}$ (b), $2 \mathrm{~K}$ (c), $15 \mathrm{~K}$ (d) and $25 \mathrm{~K}$ (e) were resolved on $1.2 \%$ agarose gel. Lane M indicates molecular size marker $(\mathrm{kb})$ and remaining lanes contained RAPD products of different halophilic bacterial isolates as indicated.

\section{Authors' contributions}

SG and PS isolated the microorganisms and performed molecular biology work. KD helped in designing, and preparing the draft of manuscript. MS helped in phylogenetic analysis. AS conceived and supervised the experiments. All authors read and approved the final manuscript.

\section{Acknowledgements}

The authors are thankful to Shoolini University, Solan for the financial and infrastructural support provided for this study.

\section{Compliance with ethical guidelines}

\section{Competing interests}

The authors declare that they have no competing interests.

Received: 29 January 2015 Accepted: 12 May 2015

Published online: 17 June 2015

\section{References}

Altschul SF, Gish W, Miller W, Myers EW, Lipman DJ (1990) Basic local alignment search tool. J Mol Biol 215:403-410

Anton J, Oren A, Benlloch S, Rodri guez-Valera F, Amann R, Rossello RM (2002) Salinibacter ruber, an new species of extremely halophilic bacteria from saltern crystallizer ponds. Int J Syst Evol Microbiol 52:485-491

Ara I, Daram D, Baljinova T, Yamamura H, Bakir MA, Suto M et al (2013) Isolation, classification, phylogenetic analysis and scanning electron microscopy of halophilic, halotolerant and alkaliphilic actinomycetes isolated from hypersaline soil. Afr J Microbiol Res 7:298-308

Arahal RD, Dewhirst EF, Paster JB, Volcani EB, Ventosa A (1996) Phylogenetic analyses of some extremely halophilic Archaea isolated from Dead Sea 
water, determined on the basis of their $16 \mathrm{~S}$ rRNA sequences. Appl Environ Microbiol 62:3779-3786

DasSarma S, Arora P (2001) Halophiles. In: Encyclopedia of Life Sciences. Nature Publishing Group, London. www.els.net.pp1-9

DasSarma P, DasSarma S (2012) Halophiles, eLS. Wiley, New York. www.els.net

Dodia MS, Joshi HR, Patel KR, Singh PS (2006) Characterization and stability of extracellular alkaline proteases from halophilic and alkaliphilic bacteria isolated from saline habitat of Coastal Gujarat, India. Braz J Microbiol 37:276-282

Dong C, Bai X, Lai Q, Xie Y, Chen X, Shao Z (2014) Draft genome sequence of Marinomonas sp. strain D104, a polycyclic aromatic hydrocarbon-degrading bacterium from the deep-sea sediment of the Arctic ocean. Genome Announc 2:e1211-e1213. doi:10.1128/genomeA.01211-13

Espinosa E, Marco-Noales E, Gomez D, Lucas-Elıo P, Ordax M, Garcias-Bonet N et al (2010) Taxonomic study of Marinomonas strains isolated from the seagrass Posidonia oceanica, with descriptions of Marinomonas balearica sp. nov. and Marinomonas pollencensis sp. nov. Int J Syst Evol Microbiol 60:93-98

Galinski EA (1993) Compatible solute of halophilic eubacteria: molecular principles, water solute interaction, stress protection. Experientia 49:487-496

Ghasemi Y, Rasoul-Amini S, Ebrahiminezhad A, Kazemi A, Shahbazia M, Talebniaa N (2011) Screening and isolation of extracellular protease producing bacteria from the Maharloo Salt Lake. Iran J Pharm Sci 7:175-180

Gisbert C, Rus AM, Bolarin MC, Lopez-Coronado JM, Arrillaga I, Montesinos C et al (2000) The yeast HAL1 gene improves salt tolerance of transgenic tomato. Plant Physiol 123:393-402

Grant WD (2004) Life at low water activity. Philos Trans R Soc Lond B Biol Sci 359:1249-1267

Greenberg AE, Clesceri LS, Eaton AD (1992) Standard method for the examination of water and waste water, 18th edn. APHA, AWWA, WPCF, Wasington DC

Hanelt I, Muller V (2013) Molecular mechanisms of adaptation of the moderately halophilic bacterium Halobacillis Halophilus to its environment. Life 3:234-243

Hedi A, Essghaier B, Cayol J, Fardeau M, Sadfi N (2014) Prokaryotic biodiversity of halophilic microorganisms isolated from Sehline Sebkha Salt Lake (Tunisia). Afr J Microbiol Res 8:355-367

Hillmann F, Fischer RJ, Bahl H (2006) The rubrerythrin-like protein Hsp21 of Clostridium acetobutylicum is a general stress protein. Arch Microbiol 185:270-276

Irshad A, Ahmad I, Kim BS (2014) Culturable diversity of halophilic bacteria in foreshore soils. Braz J Microbiol 45:563-571

Kanekar PP, Joshi AA, Kelkar SA, Borgave BS, Sarnaik SS (2008) Alkaline Lonar lake, India - a treasure of alkaliphilic and halophilic bacteria. In: The 12th World Lake Conference, pp 1765-1774

Kapardar RK, Ranjan R, Grover A, Puri M, Sharma R (2010) Identification and characterization of genes conferring salt tolerance to Escherichia coli from pond water metagenome. Bioresour Technol 101:3917-3924

Kapley A, Purohit HJ, Chhatre S, Shanker R, Chakrabarti T, Khanna P (1999) Osmotolerance and hydrocarbon degradation by a genetically engineered microbial consortium. Bioresour Technol 67:241-245

Kim D, Baik SK, Kim SM, Jung B, Shin T, Chung G et al (2007) Shewanella haliotis sp. nov., isolated from the gut microflora of abalone, Haliotis discus hannai. Int J Syst Evol Microbiol 57:2926-2931

Klahn S, Marquardt DM, Rollwitz I, Hagemann M (2009) Expression of the ggpPS gene for glucosylglycerol biosynthesis from Azotobacter vinelandii improves the salt tolerance of Arabidopsis thaliana. J Exp Bot 60:1679-1689

Kokare CR, Mahadik KR, Kadam SS, Chopade BA (2004) Isolation, characterization and antimicrobial activity of marine halophilic Actinopolyspora species AH1 from the west coast of India. Curr Sci 86:593-597

Lane DJ (1991) 16S/23S rRNA sequencing. In: Stackebrandt E, Goodfellow M (eds) Nucleic acid techniques in bacterial systematics. Wiley, Chichester, pp 115-175

Li X, Yu HY (2012) Characterization of an organic solvent-tolerant $\alpha$-amylase from a halophilic isolate, Thalassobacillus sp. LY18. Folia Microbiol 57:447-453

Litchfield CD, Gillevet PM (2002) Microbial diversity and complexity in hypersaline environments: a preliminary assessment. Ind J Microbiol Biotechnol 28:48-55
Mata AJ, Martínez-Cánovas J, Quesada E, Béjar V (2002) A detailed phenotypic characterisation of the type strains of Halomonas species. Appl Microbiol 25:360-375

Nigam VK, Singhal P, Vidyarthi AS, Mohan MK, Ghosh P (2013) Studies on keratinolytic activity of alkaline proteases from halophilic bacteria. Int J Pharm Biol Sci 4:389-399

Nozue H, Hayashi T, Hashimoto Y, Ezaki T, Hamasaki K, Ohwada K (1992) Isolation and characterization of Shewanella alga from human clinical specimens and emendation of the description of S. alga Simidu et al. 1990, 335. Int J Syst Evol Microbiol 42:628-634

Oren A (2002) Molecular ecology of extremely halophilic archaea and bacteria. FEMS Microbiol Ecol 39:1-7

Oren A (2010) Industrial and environmental applications of halophilic microorganisms. Environ Technol 31:825-834

Oren A (2014) Taxonomy of halophilic Archaea: current status and future challenges. Extremophiles 18:825-834

Patel P, Bhagalia K, Choksi N, Shah G (2010) Isolation, characterization and medium optimization of halophiles from Arabian-Sea Coast. Adv BioTech 10:16-17

Paterekt R, Smith HP (1985) Isolation and characterization of a halophilic methanogen from Great Salt Lake. Appl Environ Microbiol 50:877-881

Pedge SS, Ahirrao DS (2013) Assessment of environmental impact on Lonar Lake Water, (MS) India. Middle East J Sci Res 15:1285-1289

Roberts MF (2005) Organic compatible solutes of halotolerant and halophilic microorganisms. Saline Syst 1:5

Roohi A, Ahmed I, Iqbal M, Jamil M (2012) Preliminary isolation and characterization of halotolerant and halophilic bacteria from salt mines of Karak, Pakistan. Pak J Bot 44:365-370

Sakamoto T, Murata N (2002) Regulation of the desaturation of fatty acids and its role in tolerance to cold and salt stress. Curr Opin Microbiol 5:208-210

Sambrook J, Fritsch EF, Maniatis T (2009) Molecular cloning: a laboratory manual by Joe Sambrook, 3rd edn. Cold Spring Harbor Laboratory Press, New York

Saum S, Pfeiffer F, Palm P, Rampp M, Schuster S, Müller V, Oesterhelt D (2012) Chloride and organic osmolytes: a hybrid strategy to cope with elevated salinities by the moderately halophilic, chloridedependent bacterium Halobacillus halophilus. Environ Microbiol. doi:10.1111/j.1462-2920.2012.02770.x

Smibert RM, Krieg NR (1994) phenotypic characterization. In: Gerhardt P, Murray RG, Wood WA, Krieg NR (eds) Methods for general and molecular bacteriology ASM 5, pp 611-654

Solanki P, Kothari V (2012) Metal tolerance in halotolerant bacteria isolated from saline soil of Khambhat. Res Biotechnol 3:01-11

Solomon E, Viswalingam K (2013) Isolation, characterization of halotolerant bacteria and its biotechnological potentials. IJSRET 4:1-7

Spring S, Ludwig W, Marquez MC, Ventosa A, Schleifer KH (1996) Halobacillus gen. nov., with description of Halobacillus litoralis sp. nov. and Halobacillus trueperi sp. nov., and transfer of Sporosarcina halophila to Halobacillus halophilus comb. nov. Int J Syst Bacteriol 46:492-496

Surve W, Patil MU, Dharmadekari SM (2012) Moderately halophilic bacteria from solar salt pans of Ribander, Goa: a comparative study. Intl J Adv Biotec Res 3:635-643

Tamura K, Dudley J, Nei M, Kumar S (2007) MEGA4: molecular evolutionary genetics analysis (MEGA) software version 4.0. Mol Biol Evol 24:1596-1599

Thompson JD, Higgins DG, Gibson TJ (1994) CLUSTAL W: improving the sensitivity of progressive multiple sequence alignment through sequence weighting, position-specific gap penalties and weight matrix choice. Nucleic Acids Res 22:4673-4680

Ventosa A, Nieto JJ, Oren A (1998) Biology of aerobic moderately halophilic bacteria. Microbiol Mol Biol Rev 62:504-544

Vidyasagar M, Prakash S, Jayalakshmi SK, Sreeramulu K (2007) Optimization of culture conditions for the production of halothermophilic protease from halophilic bacterium Chromohalobacter sp. TVSP101. World J Microbiol Biotechnol 23:655-662

Vijayanand S, Hemapriya J, Selvin J, Kiran S (2012) Biodiversity of extremely halophilic bacterial strains isolated from Solar Salterns of Tuticorin, Tamilnadu, India. Int J Water Res Environ 2:01-07

Waditee R, Hibino T, Nakamura T, Incharoensakdi A, Takabe T (2002) Overexpression of a Na+ $/ \mathrm{H}^{+}$antiporter confers salt tolerance on a freshwater cyanobacterium, making it capable of growth in sea water. Proc Natl Acad Sci USA 99:4109-4114

Wisniak J (2002) The Dead Sea; a pool of chemicals. Indian J Chem Technol 9:79-87 